See discussions, stats, and author profiles for this publication at: https://www.researchgate.net/publication/307554074

\title{
Surface Modification of the Alloy Ti-7.5Mo by Anodization for Biomedical Applications
}

Article in Materials Science Forum · August 2016

DOI: 10.4028/www.scientific.net/MSF.869.913

CITATIONS

3 authors, including:

Javier Andrés Muñoz Chaves

Universidade Federal de São Carlos

17 PUBLICATIONS 69 CITATIONS

SEE PROFILE
READS

41

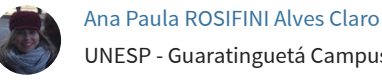

101 PUBLICATIONS 265 CITATIONS

SEE PROFILE

Some of the authors of this publication are also working on these related projects:

Project Nanotubes on Ti-Nb alloys View project

Project Resistência à corrosão de liga experimental Ti-10Mo. Influência da concentração de peróxido de hidrogênio View project 


\title{
Surface Modification of the Alloy Ti-7.5Mo by Anodization for Biomedical Applications
}

\author{
Ana Lucia do Amaral Escada ${ }^{1, a}$, Javier Andres Munoz Chaves ${ }^{1, b}$, \\ Ana Paula Rosifini Alves Claro ${ }^{1, \mathrm{c}}$
}

\author{
${ }^{1}$ Univ. Estadual Paulista - UNESP, Department of Materials and Technology, \\ Faculty of Engineering Guaratinguetá, Av. Dr. Ariberto Pereira da Cunha, 333, Pedregulho, \\ CEP 12.516-410, Guaratinguetá, SP, Brazil.
}

a analuciaescada@uol.com.br, b javier_munozch@outlook.com, ${ }^{c}$ rosifini@feg.unesp.br

Keywords: $\mathrm{TiO}_{2}$ nanotubes, Self-organization; Nanotubes; Anodization

\begin{abstract}
The purpose of this study was to evaluate the $\mathrm{TiO}_{2}$ nanotubes growth and the variation in its diameter to improve the surface properties of Ti-7.5Mo to use for biomedical applications. For the nanotubes $\mathrm{TiO}_{2}$ growth, the samples were anodized in glycerol and ammonium fluoride and divided according to the anodizing potential at $5 \mathrm{~V}$ to $10 \mathrm{~V}$ and 24 hour time. The surfaces were examined by scanning electron microscope (SEM), X-ray analysis (XRD) and contact angle measurements. The average tube diameter, ranging in size from 13 to $23 \mathrm{~nm}$, was found to increase with increasing anodizing voltage. It was also observed a decrease in contact angle in accordance with the increase in the anodizing potential. The X-ray analysis showed the presence of anatase phase in samples whose potential was $10 \mathrm{~V}$ and this condition represents a simple surface treatment for $\mathrm{Ti}$ 7.5Mo alloy that has high potential for biomedical applications.
\end{abstract}

\section{Introduction}

Titanium (Ti) and its alloys are widely used in dental and orthopedic applications due light weight and appropriate mechanical properties. Also, titanium-based alloys have excellent corrosion resistance and good biocompatibility [1].

The surface properties of materials are a very important factor to occur a good osseointegration and the topography and surface physicochemistry are elements that enhance the development of the bone around an implant [2]. To occur a better biomedical implant osseointegration is necessary to have a surface that promotes biological and cellular processes.

Over the past decade, various techniques such as micromachining [3],, grinding, polishing [4], and chemical methods like acid etching [5], alkali etching [6], and anodization [7] of titanium surface modification have been employed to fabricate implant surfaces. In recent years, a nanometer implants surface has been paramount to the survival of cells and tissue acceptance [8].

Anodization is an electrolytic passivation technique used to increase the thickness of the natural oxide layer on metal surfaces. This technique has attracted great attention in recent years due to its simplicity as well as reproducibility of the results obtained $[9,10]$. The thickness and structure of the oxide layer formed (amorphous or crystalline) depends on the applied potential between the electrodes and duration of anodization time. The structure of the oxide film formed on titanium can be anatase, a mixture of anatase and rutile, or rutile [11].

Recent studies have demonstrated that controlled anodizing titanium alloys leads to the formation of a layer of self-assembled nanotubes [12]. The diameter of these nanotubes can be controlled by anodization potential as demonstrated by Bauer et al. 2006. In their work, different anodizing potentials (from $1 \mathrm{~V}$ and $25 \mathrm{~V}$ ) were applied and self-organized porous structures with a diameter from $15 \mathrm{~nm}$ to $120 \mathrm{~nm}$ and length from $20 \mathrm{~nm}$ to $1 \mathrm{um}$ were formed [13]. In another study, Park et al. 2007 demonstrated that the response of mesenchymal cells were dependent on the diameter of the $\mathrm{TiO}_{2}$ nanotubes. They obtained nanotubes with diameter between 15 and $100 \mathrm{~nm}$ be able to accelerate cell activity when compared to other diameters and a smooth surface. [14]. 
In the present study the variation in the diameter of nanotube $\mathrm{TiO}_{2}$ was investigated according to the applied anodizing potential order to obtain $\mathrm{TiO}_{2}$ nanotubes with diameters that improve the surface properties of Ti-7.5Mo to use for biomedical applications. This alloy was choosen due to theirs excellent bulk properties, a low elastic modulus and a high strength/modulus ratio in order to obtain a better surface.

\section{Materials and methods}

The Ti-7.5Mo alloy was produced from sheets of commercially pure titanium $(99.9 \%)$ and molybdenum (99.9\%). Samples were melted in an arc furnace under an argon atmosphere. Then, the ingots were then homogenized under vacuum at $1100^{\circ} \mathrm{C}$ for $86.4 \mathrm{ks}$ to eliminate chemical segregation. They were cold worked by swaging and bars with $13 \mathrm{~mm}$ of diameter were produced. Then discs with $4 \mathrm{~mm}$ of thickness were cut and samples were divided into two groups according anodization potential.

Samples were grided with emery papers (200 to 1200) and polished with a solution formed by colloidal silica (OPS - Struers) plus 5\% oxalic acid. They were clean in the ultrasonic bath. Anodization process was performrd at $5 \mathrm{~V}$ and $10 \mathrm{~V}$ for 24 hours. After the anodization, the samples were washed with deionized water, dried, and calcined at $450{ }^{\circ} \mathrm{C}$ at a heating rate of $5{ }^{\circ} \mathrm{C}$ per minute, 1 hour of permanence. And cooled in the oven.

Surfaces were evaluated using a scanning electron microscope (SEM-FEG, XL 30 FEG, Philips) after anodizing.

X-ray diffraction (XRD) for phase analysis were realized using a Shimadzu diffractometer (Shimadzu-XRD 6000) operated using $\mathrm{Cu} \mathrm{K \alpha}$ radiation $(40 \mathrm{kV} / 30 \mathrm{~mA}$ ) with scan mode continuous and scan rate of $1.0 \mathrm{deg} / \mathrm{min}$

The wettability was evaluated by contact angle measurements. The contact angle was obtained by using the sessile drop method on an advanced Rame-Hart goniometer, model $\mathrm{n}^{\circ} 300-\mathrm{F} 1$. A microliter syringe pump was attached to a small needle in an XYZ manipulator to enable a drop to be slowly increased and decreased in size. The shape of the drop was recorded by a digital camera and the contact angles were measured from the images. The volume of each drop was $2 \mu 1$ and the average value of at least 5 drops was calculated.

\section{Results and discussion}

Figure 1 shows the micrographs of the samples after anodization at $5 \mathrm{~V}$ and $10 \mathrm{~V}$ for 24 hours. All samples were calcined at $450{ }^{\circ} \mathrm{C}$. A self-organized layer and homogeneous of the nanotubes was obtained for all conditions evaluated. For samples anodized at $5 \mathrm{~V}$ (Fig 1a) and $10 \mathrm{~V}$ (Fig 1b), the average pore diameter was $13.68 \mathrm{~nm}$ and $22.83 \mathrm{~nm}$, respectively. It could be concluded that the increase of the voltage and diameter are related.

These results were similar with Lockman et al.(2010) [15] who concluded that the tube diameter is linearly dependent on the applied potential during the growth of nanotubes. According Macak et al. (2008) [16] either, diameter changes linearly with the applied potential during the growth of nanotubes and it was also observed in our results. Furthermore, the diameter of the nanotube in the condition of $5 \mathrm{~V}$ is smaller $(13.68 \mathrm{~nm})$ than for $10 \mathrm{~V}(22.83 \mathrm{~nm})$ and the nearest ideal condition for adhesion and proliferation cell, according to Park et al. 2007 [14]. 

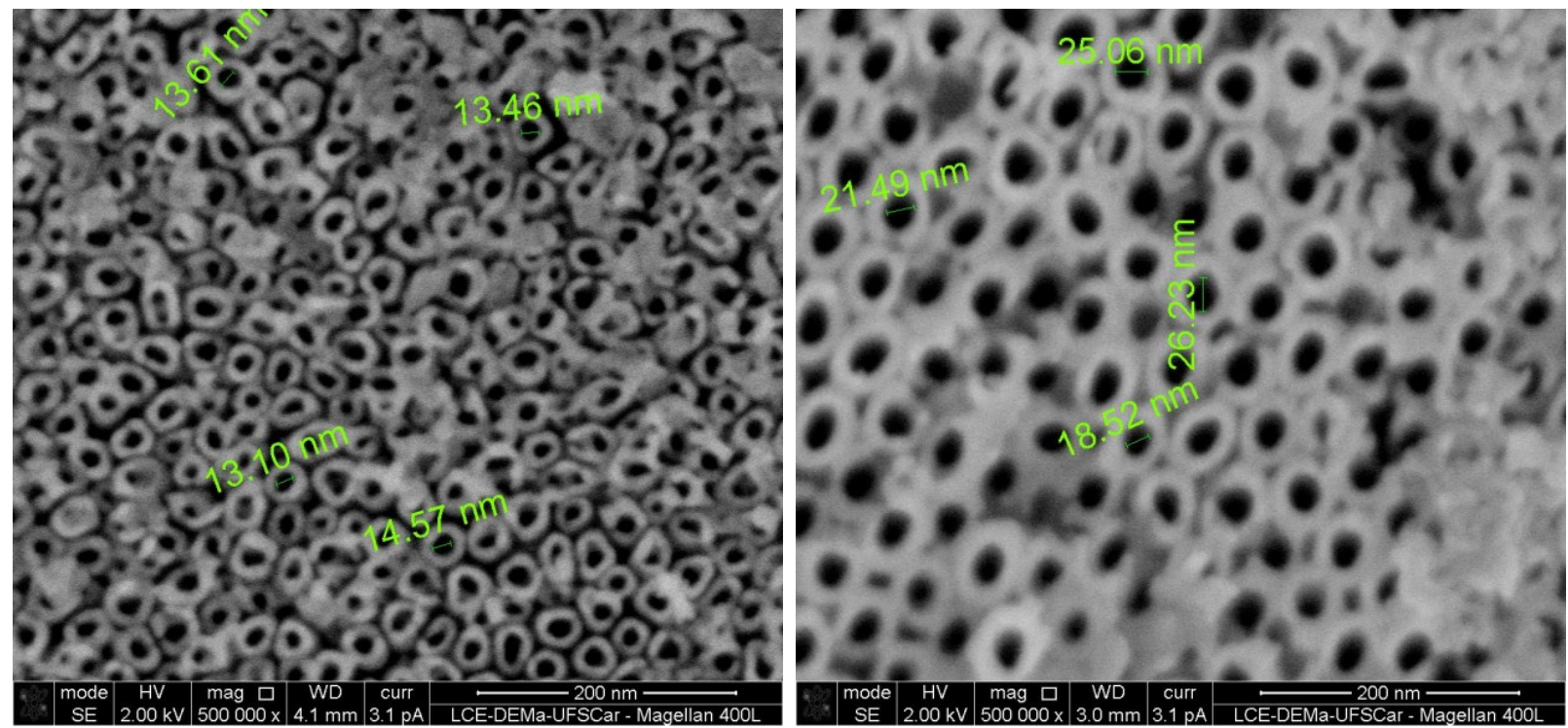

Fig. 1 - Field emission gun scanning electron microscopy images (SEM-FEG): (a) anodized $\mathrm{Ti}-7.5 \mathrm{Mo}-5 \mathrm{~V}-24 \mathrm{~h}-450^{\circ} \mathrm{C}$; (b) anodized Ti-7.5Mo - $10 \mathrm{~V}-24 \mathrm{~h}-450^{\circ} \mathrm{C}$

Figure 2 shows the X-ray diffraction patterns for samples anodized at $5 \mathrm{~V}$ and $10 \mathrm{~V}$ for 24 hours and calcined at $450{ }^{\circ} \mathrm{C}$. Structural analyses shows that the surface consisted of a $\mathrm{TiO}_{2}$ layer in amorphous state and diffraction peaks related to the substrate ( $\alpha$-Ti phase) in the XRD pattern were observed for both anodization $(5 \mathrm{~V}$ and $10 \mathrm{~V})$, but the X-ray analysis showed the presence of anatase phase $\left(25^{\circ}, 48^{\circ}, 53^{\circ}\right.$ and $\left.54^{\circ}\right)$ is only present for samples whose potential is $10 \mathrm{~V}$. The obtained peaks in XRD pattern are consistent with JCPDS Card No. 84-1286.

According Park et al. 2007 [14], $\mathrm{TiO}_{2}$ exists in three different allotropic form, anatase, rutile and brukite, therefore the $\mathrm{TiO}_{2}$ nanotubes can also be found in these different phases, but the anatase most desired to be biocompatible. In this study, the anatase phase is present only in samples anodized at $10 \mathrm{~V}$, and its appearance is probably due to the greater diameter of the $\mathrm{TiO}_{2}$ nanotubes formed during the application of this potential, making this to the better condition for biomedical applications.

The graphic 1 showed the contact angle measurements for two conditions studied. For samples anodized at $5 \mathrm{~V}$, the contact angle was $7.8^{\circ}$, and for samples anodized at $10 \mathrm{~V}$, it was $15.3^{\circ}$. It is possible to observe that in this case, the increasing of the anodization potential increased the nanotube diameter and the contact angle. The samples anodized at $5 \mathrm{~V}$ showed that the nanotube diameter was $13.68 \mathrm{~nm}$ with contact angle of $7.8^{\circ}$, while the samples anodized at $10 \mathrm{~V}$ showed that the nanotube diameter was $22.83 \mathrm{~nm}$ with contact angle of $15.3^{\circ}$. Surface wettability (hydrophobicity/hydrophilicity) is one of the most important parameters affecting the biological response of an implanted biomaterial. Wettability affects protein adsorption, platelet adhesion/activation, blood coagulation and cell and bacterial adhesion [17-18]. Highly hydrophilic surfaces seem more desirable than hydrophobic ones in view of their interactions with biological fluids, cells and tissues [19]. According to Lim and Donahue [20], the relationship between the contact angle and wetting occurs in reverse on the same surface. Therefore, a decrease of this angle increases the capacity for surface wettability. 


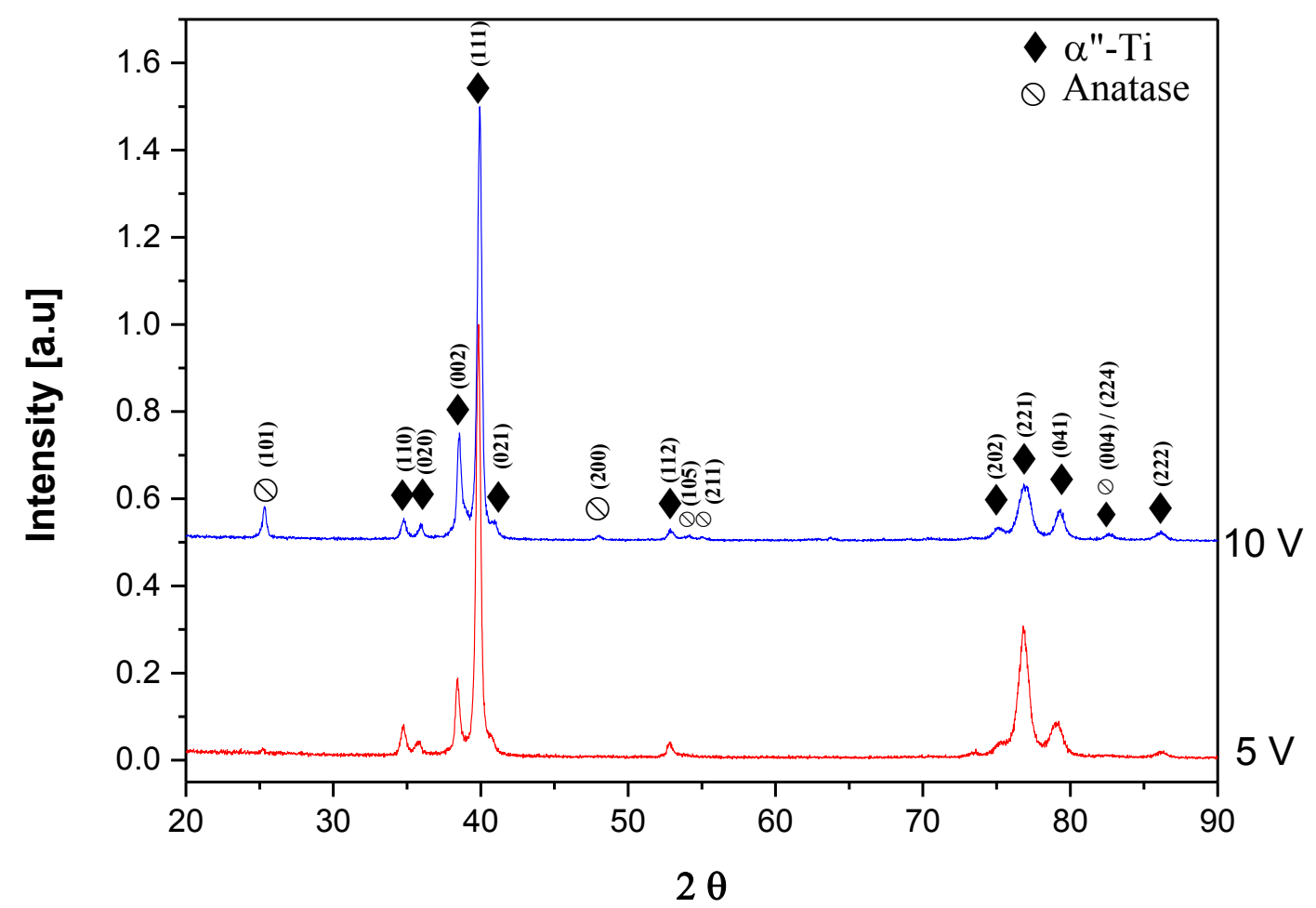

Fig. 2 - X-ray diffraction patterns for the samples anodized Ti-7.5Mo - 5V-24h- $450^{\circ} \mathrm{C}$ and $10 \mathrm{~V}-24 \mathrm{~h}-450^{\circ} \mathrm{C}$

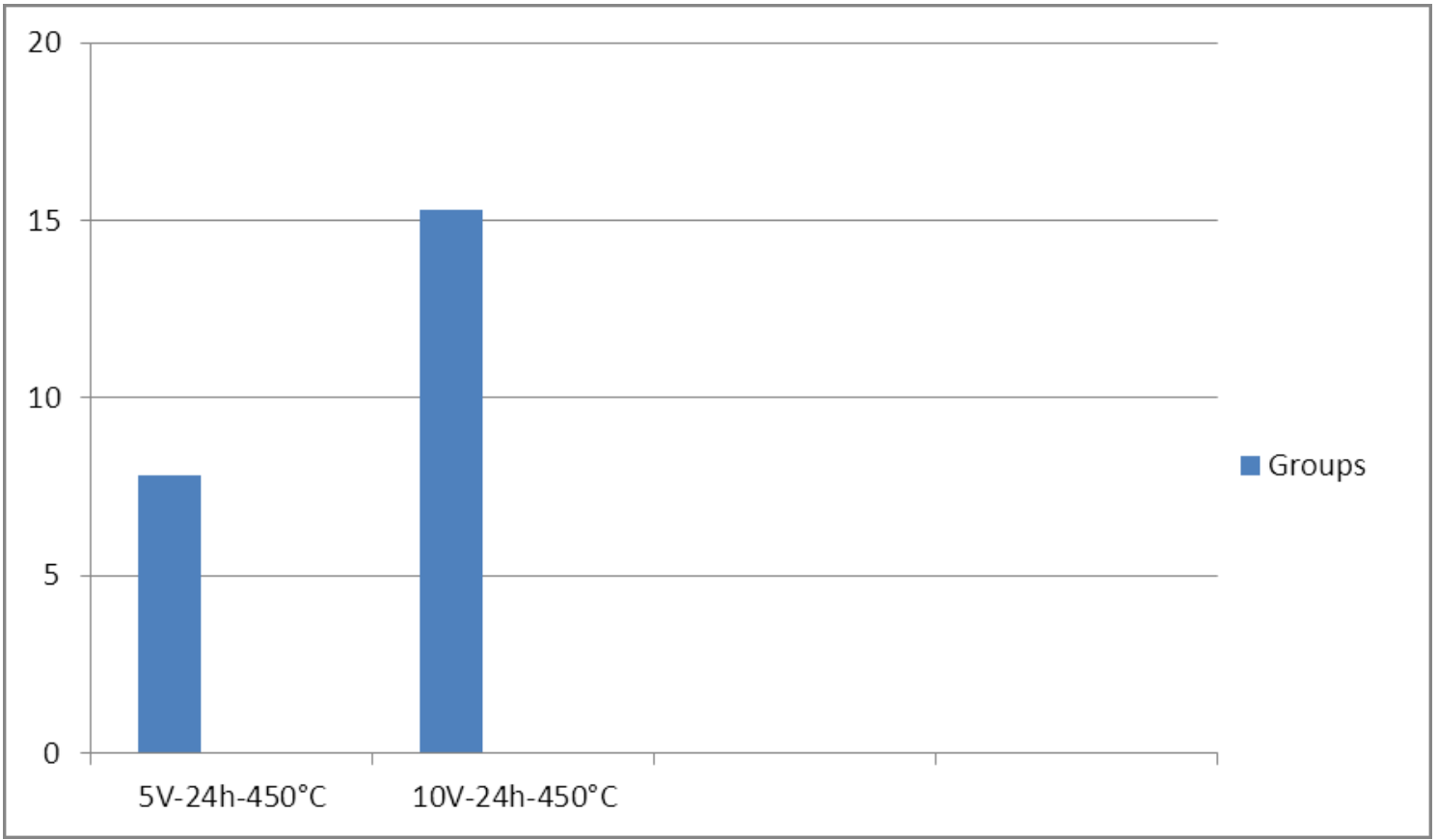

Fig. 3 - Contact angle measurements

\section{Conclusion}

In this study, the effects of anodization potential difference applied on the formation and dimensions of the titania nanotubes were investigated. Self-organized porous nano-tubular titania was formed anodically on Ti-7.5Mo from electrolyte containing glycerol and $0.25 \% \mathrm{NH}_{4} \mathrm{~F}$.

It was found that anodization potential contributed mainly to tuning the nanotube diameter. The increasing of the anodization potential increased the nanotube diameter and the contact angle. 
For samples anodized at $5 \mathrm{~V}$ the nanotube layer is amorphous and it is crystalline to samples anodized at $10 \mathrm{~V}$. In this study, the anatase phase is present only in samples anodized at $10 \mathrm{~V}$, and its appearance is probably due to the greater diameter of the $\mathrm{TiO}_{2}$ nanotubes formed during the application of this potential, making this to the better condition for biomedical applications. The anatase oxide phase is essential for increasing osseointegration because amorphous surfaces can be easily dissolved in body fluids.

\section{Acknowledgements}

Financial support for this work was provided by Fundação de Amparo à Pesquisa do Estado de São Paulo, FAPESP Process-2013/08200-9.

\section{References}

[1] J. Choi, R.B. Wehrspohn, J. Lee, U. Gosele: Electrochimica Acta Vol. 49 (2004), p. 2645.

[2] Y.T. Sul, C. Johansson, A. Wennerberg, L.R. Cho, B.S. Chang, T. Albrektsson: Int J Oral Maxillofac Implants Vol. 20 (2005), p. 349.

[3] N. Sykaras, A.M. Iacopino, V.A. Marker, R.G. Triplett, R.D. Woody: Int. J. Oral Maxillofac. Implants Vol. 15 (2000), p. 675.

[4] M.E. Barbour, D.J. O’Sullivan, H.F. Jenkinson, D.C. Jagger: J. Mater. Sci. Mater. Med. Vol. 18 (2007), p. 1439.

[5] S. Szmukler-Moncler, D. Perrin, V. Ahossi, G. Magnin, J.P. Bernard: J. Biomed. Mater. Res. B Appl. Biomater. Vol. 68 (2004), p. 149.

[6] S. Nishiguchi, S. Fujibayashi, H.M. Kim, T. Kokubo, T. Nakamura: J. Biomed. Mater. Res. A. Vol. 67 (2003), p. 26.

[7] K.H. Park, S.J. Heo, J.Y. Koak, S.K. Kim, J.B. Lee, S.H. Kim, Y.J Lim: J. Oral Rehabil. Vol. 34 (2007), p. 517.

[8] H. Liu, T.J Webster: Biomaterials Vol. 28 (2007), p. 354.

[9] Y.T. Sul: Biomaterials Vol. 24 (2003), p. 3893.

[10] A.S. Karakoti, R. Filmalter, D. Bera, S.V. Kuchibhatla, A. Vincent, S. Seal: J. Nanosci. Nanotechnol. Vol. 6 (2006), p. 2084.

[11] J.M. Macak, H. Tsuchiya, A. Ghicov, K. Yasuda, R. Hahn, S. Bauer, P. Schmuki: Curr. Opin. Solid State Mater. Sci Vol. 11 (2007), p. 3.

[12] J.M Macak, H. Tsuchiya, P. Schmuki: Angew Chem. Int Ed. Engl. Vol. 44 (2005), p. 2100.

[13] B. Sebastian, K. Sebastian, S. Patrik: Electrochemistry Communications Vol. 8 (2006), p. 1321.

[14] J. Park, S. Bauer, von der MK, P. Schmuki: Nano Lett. Vol. 7 (2007), p. 1686.

[15] Z. Lockman, S. Sreekantan, S. Ismail, L. Schmidt-Mende, J.L. MacManus-Driscoll: Journal of Alloys and Compounds Vol. 503 (2010), p. 359.

[16] J.M. Macak, H. Hildebrand, U. Marten-Jahns, P. Schmuki: Journal of Electroanalytical Chemistry Vol. 621 (2008), p. 254.

[17] Y. Wei-qiang, J. Xing-quan, Z. Fu-qiang, X. Ling: Journal of Biomedical Materials Research Part A Vol. 94 (2010), p. 1012.

[18] J.H. Choee, S.J. Lee, Y.M. Lee, J.M. Rhee, H.B. Lee, G. Khang: J Appl Polym Sci. Vol. 92 (2004), p. 599.

[19] N. Faucheux, R. Schweiss, K. Lutzow, C. Werner, T. Groth: Biomaterials Vol. 25 (2004), p. 2721.

[20] G. Zhao, Z. Schwartz, M. Wieland, F. Rupp, J. Geis-Gerstorfer, D.L. Cochran, B.D. Boyan: J Biomed Mater Res A. Vol. 74 (2005), p. 49. 